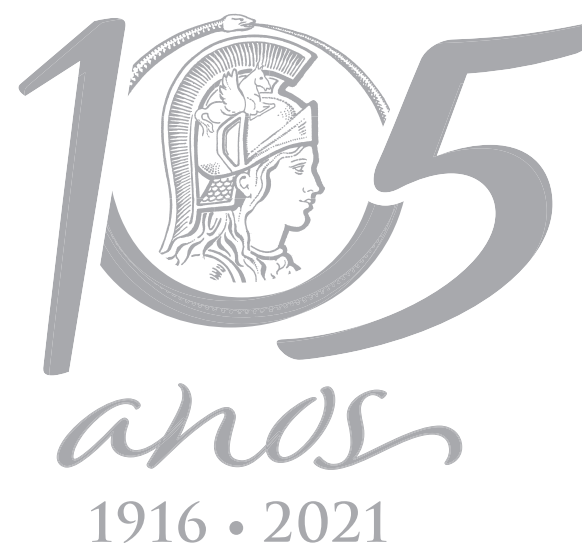

\title{
MICROBIOLOGY
}

\section{Importance of palynology in the taxonomy of Piptolepis Sch.Bip. (Asteraceae: Lychnophorinae), a genus endemic to Brazil}

\author{
RAQUEL M.B. SOUZA-SOUZA, GRACE K.R. DE SOUSA, ROBERTO L. ESTEVES, \\ CLAUDIA B.F. MENDONÇA \& VANIA GONÇALVES-ESTEVES
}

\begin{abstract}
Lychnophorinae comprises 19 genera and 117 species. Its representatives are found mostly in the rocky grasslands ("campos rupestres") of Minas Gerais, Bahia, and Goiás States, Brazil. This study presents a palynological investigation of 10 species belonging to the genus Piptolepis, endemic to the rocky grasslands of the Espinhaço Mountains, in Minas Gerais State. The plant material used in this investigation was obtained from specimens deposited in Brazilian herbaria. Pollen grains were processed by the acetolysis method, measured, described, and photomicrographed in light microscopy and scanning electron microscopy. Morphological observations revealed Piptolepis pollen to be large, prolate spheroidal in most species, 3-colporate, ectoapertures long, sexine subechinolophate or sublophate. Endoapertures vary from almost circular, lalongate or lalongate, with a median constriction observed only in three species. Three types of spines were identified: prostrate and disorganized, elongated and narrow, and conical, erect, apex acute in the other species. This first palynological study of Piptolepis species allowed the separation of representatives of the genus using pollen keys. The most significant characters were pollen shape, ornamentation, endoaperture, and presence of median constriction in the endoaperture. The findings presented here do not support the infrageneric classification of Piptolepis, as pollen characters were not unique to any section.
\end{abstract}

Key words: rocky grasslands, Lychnophorinae, Minas Gerais, palynotaxonomy, pollen.

\section{INTRODUCTION}

The Vernonieae is one of the largest tribes of the family Asteraceae, consisting of about 129 genera and 1,100 species distributed in all tropical regions of the world. The tribe has two centers of diversification: southeastern Brazil and central Africa (Robinson 1999, 2007, Keeley \& Robinson 2009). Its 129 recognized genera were grouped into 21 subtribes mainly based on inflorescence pattern, pollen morphology, chemical composition, and chromosome number (Keeley \& Robinson 2009), but newly Loeuille et al. (2015b) in their study on the systematics and evolution of Syncephaly in American Vernonieae synonimized Centratherinae and Sipolisiinae under Lychnophorinae, reducing the number of subtribes to 19.

The importance of palynology in the taxonomy of Vernonieae is evidenced by the study of Robinson (1999), in which pollen characters were fundamental for the separation of several genera from Vernonia Schreb. Many other studies provided valuable contributions to the classification of groups and species of Vernonieae, such as, for instance, Mendonça et al. (2007a, b, 2009, 2010), Peçanha et al. (2001), Souza-Souza et al. (2016) and Siniscalchi 
et al. (2017), who examined the palynology of several representatives of the tribe, reinforcing consistency among genera and distinction between species.

Lychnophorinae, an important subtribe of the Vernonieae, comprises 19 genera and about 120 species. Most species are distributed in the Brazilian Cerrado, predominantly in rocky grasslands ("campos rupestres"), with the exception of one species distributed to Bolivia and a weedy species that shows pantropical distribution (Loeuille et al. 2015a, 2019, Bringel Jr. et al 2019). Taxonomic considerations based on molecular and morphological data resulted in the expansion of the subtribe to make it monophyletic. Piptolepis Sch.Bip. is one of the genera subordinate to Lychnophorinae.

The genus Piptolepis, represented by 13 species, is endemic to rocky grasslands ("campos rupestres") of the Espinhaço Mountains in Minas Gerais State and the Central Plateau of Goiás State, Brazil. Its taxa are characteristically shrubby with a solitary terminal capitulum or few capitula forming a terminal synflorescence. Padlike leaf sheath and weakly imbricate caducous phyllaries. The pappus is biseriate, with bristles flattened, the outer series sometimes shorter than the inner series and usually deciduous (Hind 2003, Robinson 2006, Loeuille et al. 2019). Due to the high degree of endemism, low number of analyzed specimens and anthropic pressures, $40 \%$ of the Piptolepis taxa are included in the Red List of Endangered Species (CNCflora 2020).

Schultz-Bipontinus (1863) divided Piptolepis into two sections: Microphyllum and Macrophyllum. The author placed narrowleaved species with solitary capitula in sect. Microphyllum [= sect. Piptolepis, which was described by Jeffrey \& Hind (1994) and included P. ericoides Sch.Bip., P. buxoides Sch. Bip., P. imbricata (Gardner) Sch.Bip., and P. leptospermoides (Mart. ex DC.) Sch.Bip.] and broad-leaved species with grouped capitula in sect. Macrophyllum, including P. martiana (Gardner) Sch.Bip., P. oleaster (Mart. ex DC.) Sch. Bip., and P. pseudomyrtus (A.St.-Hil.) Sch.Bip (syn. P. monticola Loeuille). Some species of Piptolepis have characteristics of both sections and therefore do not fit into the SchultzBipontinus classification (1863).

Loeuille et al. (2012a) described three new Piptolepis species (P. schultziana Loeuille and D.J.N. Hind, P. campestris Semir and Loeuille, and P. monticola Loeuille) and included P. campestris in sect. Macrophyllum. P. schultziana could not be placed in either section defined by SchultzBipontinus (1863) because it has broad leaves and solitary capitula, indicating that further studies on Piptolepis taxonomy are needed. In 2019, two new species were described, $P$. rosmarinifolia Bringel, J.B. Candido \& Loeuille, occurring in the Central Plateau of Goiás State (Bringel Jr. et al 2019), and P. riparia Loeuille, Semir \& Pirani, occurring in the "campos rupestres" of Minas Gerais State (Loeuille et al. 2019), and P. pabstii (G.M. Barroso) Loeuille, Semir \& Pirani was proposed as a new combination for Eremanthus pabstii G.M. Barroso (Loeuille et al. 2019).

Given the importance of palynology for Asteraceae, particularly Vernonieae, the lack of palynological studies on Piptolepis, and the several taxonomic changes in the genus, this study aimed to analyze the pollen types of 10 Piptolepis species and contribute to their delimitation.

\section{MATERIALS AND METHODS}

The plant material examined in this study was obtained from specimens deposited in the following herbaria: Herbarium of the National Museum of Rio de Janeiro (R), Herbarium Urbelandense (HUFU), Herbarium of the Rio de 
Janeiro Botanical Garden (RB), and Herbarium Bradeanum (HB). The material examined is listed in Appendix 1.

Three of the 13 species that constitute the genus Piptolepis ( $P$. pabstii, P. riparia, and $P$. rosmarinifolia), other closely related genera of Piptolepis have been sampled and analyzed. All microscope slides were deposited in the botanical collection of the Álvaro Xavier Moreira Laboratory of Palynology (Department of Botany, National Museum of Rio de Janeiro, Federal University of Rio de Janeiro, Brazil).

Pollen grains were prepared for light microscopic ( $L M$ ) examination by the acetolysis method of Erdtman (1960), with the modifications proposed by Melhem et al. (2003). Acetolyzed pollen specimens were analyzed within 7 days of preparation, in accordance with the recommendations of Salgado-Labouriau (1973). Twenty-five measurements were taken of the polar (PD) and equatorial (ED) diameters of pollen grains in equatorial view on a minimum of three slides (Salgado-Labouriau et al. 1965). The data were treated statistically to obtain the arithmetic mean, sample standard deviation, mean standard deviation, and 95\% confidence interval (Cl 95\%). Other pollen parameters: equatorial diameter in polar view (EDPV), apocolpium size (SA), apertures, and exine thickness were determined in 10 pollen grains on a minimum of three slides; the results are presented as arithmetic mean. The terminology used in the description of pollen size, shape, aperture number, and sexine ornamentation follows the glossary of Punt et al. (2007). Description of the polar area and the aperture size follows the classification established by Faegri \& Iversen (1966) for the polar area index.

Non-acetolyzed pollen samples were used for scanning electron microscope (SEM) analysis. First, two or three anthers were removed from the flowers or flower buds of each specimen.
Pollen grains were released from the anthers and then mounted on metal stubs with doublesided carbon tape. Samples were sputter-coated with gold for about 3 min and examined under a Jeol JSM-6510 scanning electron microscope at the Laboratory of Optical and Scanning Microscopy of the Federal University of Rio de Janeiro or sputter-coated with platinum for about 3 min and examined under a FEI Helios NanoLab DualBeam G3 CX at the National Institute of Technology (Rio de Janeiro, Brazil).

\section{RESULTS}

This study investigated the pollen morphology of 10 species of the genus Piptolepis, namely P. buxoides (Less.) Sch.Bip. (Figure 1a-c), P. campestris Semir \& Loeuille (Figure 1d-h), P. ericoides Sch.Bip. (Figure 1i-l), P. gardneri Baker (Figure 2a-d), P. glaziouana Beauverd (Figure 2e-h), P. imbricata (Gardner) Sch.Bip. (Figure 2i-l), P. leptospermoides (Mart. ex DC.) Sch.Bip. (Figure 3a-b), P. monticola Loeuille (Figure 3c-f), P. oleaster (Mart. ex DC.) Sch.Bip. (Figure 3g-i), and P. schultziana Loeuille \& D.J.N. Hind (Figure $3 j-1)$.

The pollen grains of Piptolepis species are isopolar, large, prolate-spheroidal in most species, oblate-spheroidal in $P$. buxoides, $P$. ericoides, and $P$. glaziouana, and spheroidal in $P$. leptospermoides and P. oleaster; amb subcircular; polar area small; 3-colporate; sexine subechinolophate or sublophate (intermediate between echinolophate and subechinolophate) (Tables I and II).

Aperture: 3-colporate (Figures 1d, f, 3e), ectoaperture long (greatest length ca. $30.6 \mu \mathrm{m}$ in P. gardneri, and smallest length ca. $20.7 \mu \mathrm{m}$ in P. imbricata) and wide (largest width ca. 9.4 $\mu \mathrm{m}$ in P. schultziana, and smallest width ca. 3.0 $\mu \mathrm{m}$ in $P$. gardneri); endoaperture nearly circular in $P$. leptospermoides, slightly lolongate in $P$. schultziana, lolongate in P. glaziouana, slightly 

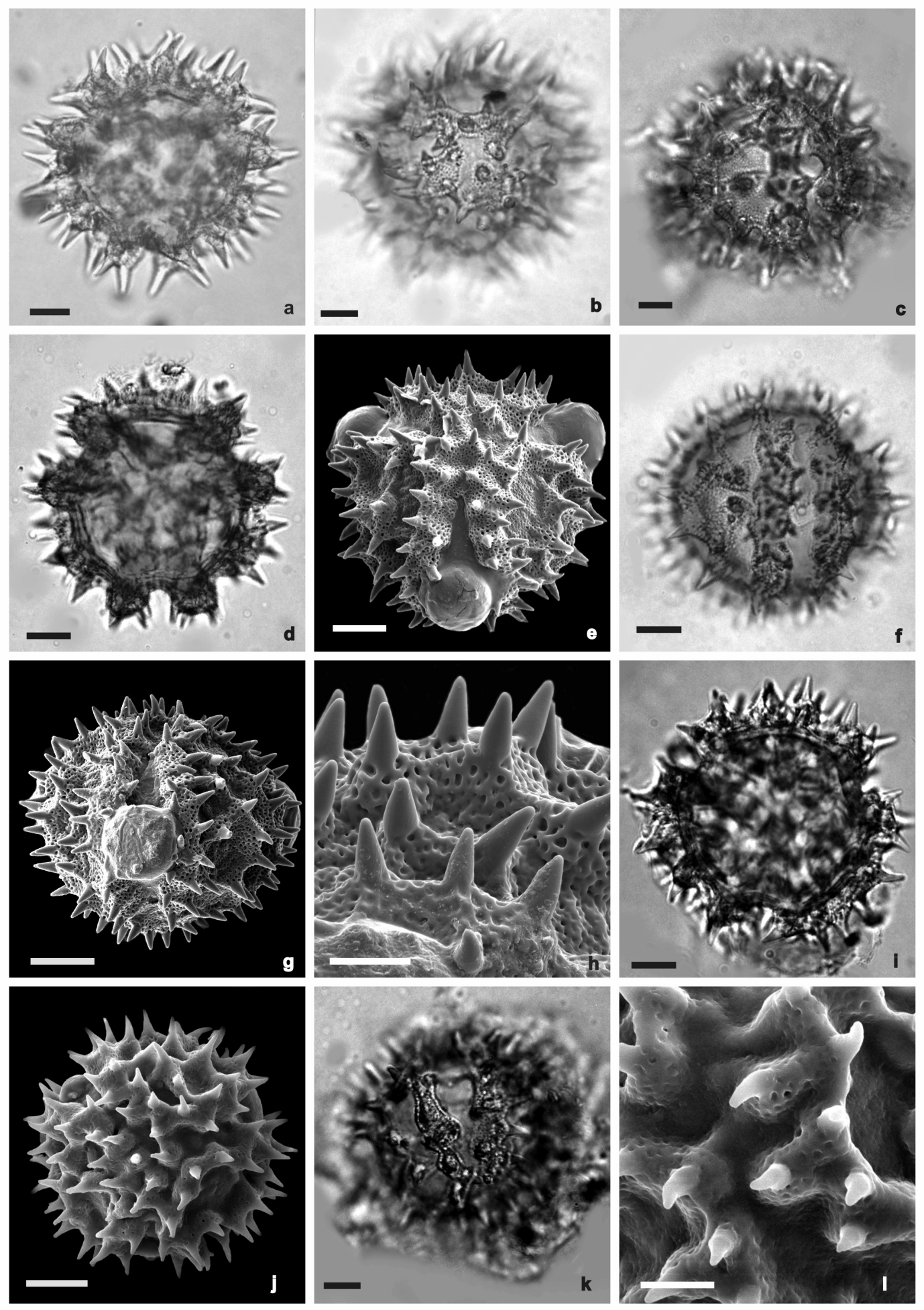

Figure 1. Light microscopy (LM) and scanning electron microscopy (SEM) images of pollen grains of Piptolepis species. P. buxoides - a. polar view, optical section (ML), b. surface (ML), c. equatorial view, general aspect and aperture (ML). P. campestris - d. polar view, optical section (ML), e. general aspect (SEM), f, g. equatorial view, general aspect and aperture (ML and SEM), h. surface detail (SEM). P. ericoides - i. polar view, optical section (ML), j. general aspect (SEM), k. equatorial view, aperture (ML), l. surface detail (SEM). Scale bar: $10 \mu \mathrm{m}(\mathrm{a}-\mathrm{g}, \mathrm{i}-\mathrm{k}), 1 \mu \mathrm{m}(\mathrm{h}, \mathrm{l})$. 
lalongate in P. gardneri, and clearly lalongate in the other species. The largest endoaperture length was observed in P. schultziana (ca. 10.8 $\mu \mathrm{m}$ ) and the smallest in P. gardneri (ca. 2.0 $\mu \mathrm{m}$ ). The largest endoaperture width (ca. 10.0 $\mu \mathrm{m})$ was found in P. ericoides, P. monticola, and P. schultziana and the smallest (ca. 2.6 $\mu \mathrm{m}$ ) in P. gardneri (Table III). Endoperture with median constriction in $P$. ericoides (Figure $1 \mathrm{k}$ ), and $P$. monticola (Figure 3e), without median constriction in P. buxoides (Figure $1 b$ ) and $P$. glaziouana (Figure 2f).

Exine: thick (largest thickness ca. $16.4 \mu \mathrm{m}$ in P. glaziouana and smallest thickness ca. $13.6 \mu \mathrm{m}$ in P. buxoides and P. gardneri); sexine subechinolophate in all species except $P$. imbricata (Figure 2j, k). Muri high, sinuous, densely perforated in most taxa, with small lacunae and perforations inside lacunae. In P. glaziouana (Figure 2e, g, h), lacunae are large and some contain isolated spines; in $P$. campestris (Figure $1 \mathrm{e}-\mathrm{g}$ ), sexine densely perforated, with $\mathrm{Y}$-shaped muri in the apocolpium resulting from a lack of lacunae; in P. imbricata (Figure $2 \mathrm{j}, \mathrm{l}$ ), lacunae shallow sublophate (intermediate between echinolophate and subechinolophate) and densely perforated. Spines conical, erect, apex acute in $P$. campestris and most taxa, elongated and narrow in P. oleaster (Figure 3i), prostrate, disorganized in P. monticola (Figure 3c, e, f); spine size and distance vary greatly between species. The largest spine length was found in P. monticola (ca. $12.8 \mu \mathrm{m})$ and the smallest in $P$. campestris (ca. $9.6 \mu \mathrm{m})$. The largest spine width was found in P. monticola (ca. $7.0 \mu \mathrm{m}$ ) and the smallest in P. buxoides (ca. $2.2 \mu \mathrm{m})$; and the largest distance between spines was found in P. monticola (ca. $12.1 \mu \mathrm{m})$ and the smallest in $P$. buxoides (ca. $7.6 \mu \mathrm{m}$ ) (Table III). The sexine is always thicker than the nexine.

\section{Pollen key for Piptolepis species}

1. Sublophate (intermediate between echinolophate and subechinolophate) sexine...... P. imbricata
1. Subechinolophate sexine

2. Spheroidal or oblate spheroidal pollen grains 3. Spheroidal pollen grains

4. Endoaperture nearly circular $(5.8 \times 6.0 \mu \mathrm{m}), \mathrm{Cl}$ 95\% PD =53.7-55.9 $\mu \mathrm{m}$............... P. leptospermoides

4. Endoaperture lalongate $(5.0 \times 8.0 \mu \mathrm{m}), \mathrm{Cl} 95 \%$ $\mathrm{PD}=61.6-63.4 \mu \mathrm{m}$ P. oleaster

3. Oblate spheroidal pollen grains

5. Endoaperture with median constriction, Cl 95\% PD $=71.7-73.6 \mu \mathrm{m}$. P. ericoides

5. Endoaperture without median constriction, $\mathrm{Cl}$ 95\% PD $<70.0 \mu \mathrm{m}$

6. Sexine without lacunae large and without isolated spines, endoaperture lalongate (5.2x8.5 $\mu \mathrm{m}), \mathrm{Cl}$ 95\% PD = 49.1-50.5 $\mu \mathrm{m}$, spines 7.6x2.2 $\mu \mathrm{m}$.

P. buxoides

6 . Sexine with lacunae are large and some contain isolated spines, endoaperture lolongate (9.6×7.0 $\mu \mathrm{m}), \mathrm{Cl}$ 95\% PD = 60.1-61.8 $\mu \mathrm{m}$, spines ca. 12.0×4.8 $\mu \mathrm{m}$. P. glaziouana

2. Prolate spheroidal pollen grains

7. Endoaperture lalongate

8. Endoperture with median constriction, spines disorganized, prostrate, muri without Y-shaped muri in the apocolpium..............................P. monticola

8. Endoperture without median constriction, spines conical, erect, apex acute with Y-shaped muri in the apocolpium...........................................P. campestris

7. Endoaperture nearly lalongate or nearly lolongate

9. Endoaperture nearly lalongate $(2.0 \times 2.4 \mu \mathrm{m})$, ectoaperture ca. $30.6 \mu \mathrm{m}$ in length, Cl 95\% PD $=56.4-59.0 \mu \mathrm{m}$ ..$P$. gardineri

9. Endoaperture nearly lolongate $(10.8 \times 10.0 \mu \mathrm{m})$, ectoaperture ca. $28.5 \mu \mathrm{m}$ in length, $\mathrm{Cl}$ 95\% PD $=65.2-69.8 \mu \mathrm{m}$. . P. schultziana 

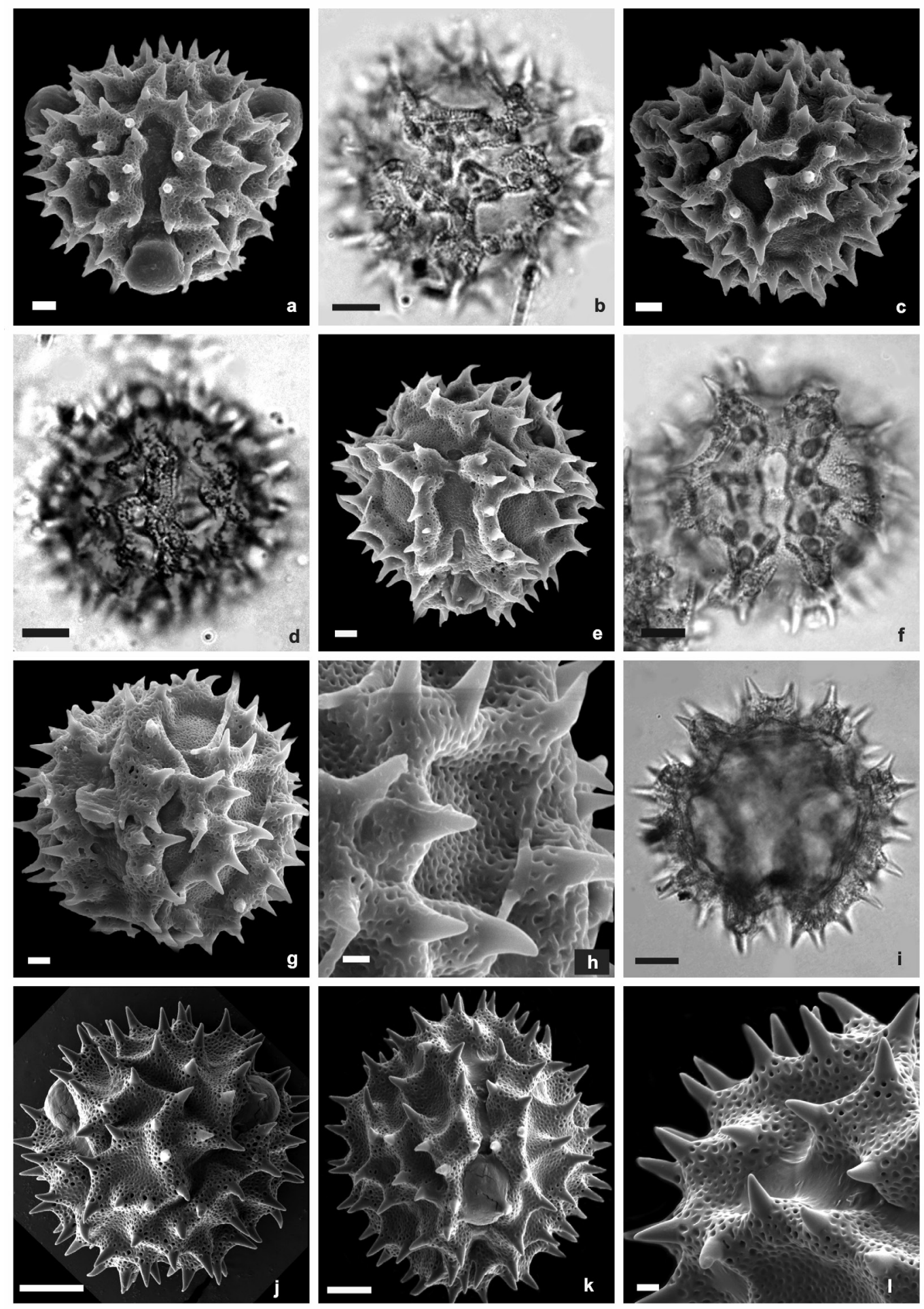

Figure 2. Light microscopy (LM) and scanning electron microscopy (SEM) images of pollen grains of Piptolepis species. P. gardneri - a. polar view, general aspect (SEM), b. surface (ML), c. mesocolporus (SEM). d. equatorial view, general aspect and aperture (ML). P. glaziouana - e. polar view, general aspect (SEM), f. equatorial view, general aspect and aperture (ML), g. mesocolporus (SEM), h. surface detail (SEM). P. imbricata - i. polar view, optical section (ML), j. general aspect, mesocolporus (SEM), k. equatorial view, aperture (SEM), l. surface detail (SEM). Scale bar: 5 $\mu \mathrm{m}(\mathrm{a}, \mathrm{c}, \mathrm{e}, \mathrm{g}), 10 \mu \mathrm{m}$ (b, d, f, i, j, k), $1 \mu \mathrm{m}$ (h, l). 

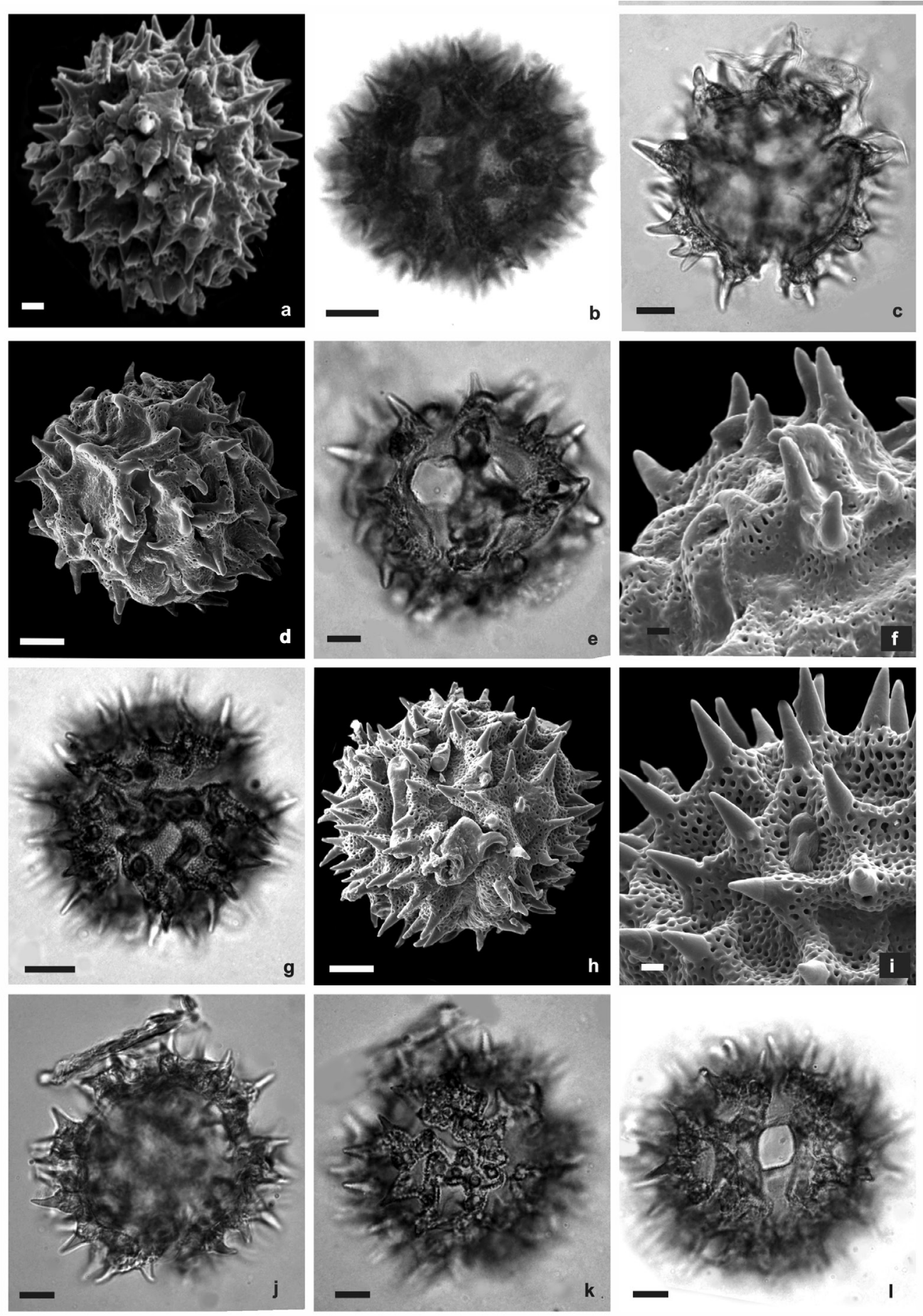

Figure 3. Light microscopy (LM) and scanning electron microscopy (SEM) images of pollen grains of Piptolepis species. P. leptospermoides - a. polar view, general aspect (SEM), b. equatorial view, aperture (ML). P. monticola - c. polar view, optical section (ML), d. polar view, apocolpus (SEM), e. equatorial view, aperture (ML), f. surface detail (SEM). P. oleaster - g. polar view, surface (ML), h. equatorial view, aperture (SEM), i. surface detail (SEM). P. schultziana - j. polar view, optical section (ML), k. general aspect, surface (ML), l. equatorial view, aperture (ML). Scale bar: $5 \mu \mathrm{m}(\mathrm{a}-\mathrm{e}, \mathrm{g}, \mathrm{h}, \mathrm{j}-\mathrm{l}), 1 \mu \mathrm{m}$ (f, i). 
Table I. Measurements (in $\mu \mathrm{m}$ ) of pollen grains in equatorial view of Piptolepis species. $\mathrm{x}^{-}$- arithmetic mean; $\mathbf{s}_{\mathrm{x}^{-}}$standard deviation; $\mathrm{Cl}$ - confidence interval; $\mathrm{P} / \mathrm{E}$ - relationship between the polar and equatorial diameters.

\begin{tabular}{|c|c|c|c|c|c|c|c|}
\hline Species & \multicolumn{3}{|c|}{ Polar diameter } & \multicolumn{3}{c|}{ Equatorial diameter } & P/E \\
\hline & Range & $\mathbf{x}^{-} \pm \mathbf{s}_{\mathbf{X}}^{-}$ & $\mathbf{C l ~ 9 5 \%}$ & Range & $\mathbf{x}^{-} \pm \mathbf{s}_{\mathbf{X}}^{-}$ & $\mathbf{C l ~ 9 5 \%}$ & \\
\hline P. buxoides & $60.0-68.7$ & $65.5 \pm 0.4$ & $64.5-66.4$ & $58.7-68.7$ & $66.3 \pm 0.4$ & $65.3-67.2$ & 0.99 \\
\hline P. campestri & $57.5-63.7$ & $60.3 \pm 0.4$ & $59.5-61.1$ & $55.0-62.5$ & $58.6 \pm 0.5$ & $57.4-59.7$ & 1.02 \\
\hline P. ericoides & $67.5-75.0$ & $72.7 \pm 0.4$ & $71.7-73.6$ & $70.0-75.0$ & $72.9 \pm 0.3$ & $72.2-73.7$ & 0.99 \\
\hline P. gardneri & $50.0-63.7$ & $57.7 \pm 0.6$ & $56.4-59.0$ & $50.0-60.0$ & $57.5 \pm 0.6$ & $55.7-58.3$ & 1.01 \\
\hline P. glaziouana & $57.5-65.0$ & $60.9 \pm 0.4$ & $60.1-61.8$ & $60.0-65.0$ & $62.9 \pm 0.3$ & $62.2-63.5$ & 0.97 \\
\hline P. imbricata & $50.0-65.0$ & $58.2 \pm 0.8$ & $56.5-59.9$ & $47.5-61.2$ & $55.0 \pm 0.9$ & $53.0-59.9$ & 1.05 \\
\hline P. leptospermoides & $50.0-57.5$ & $54.8 \pm 0.5$ & $53.7-55.9$ & $47.5-58.7$ & $53.5 \pm 0.6$ & $52.2-54.9$ & 1.00 \\
\hline P. monticola & $62.5-71.2$ & $66.1 \pm 0.4$ & $65.8-67.1$ & $60.0-66.2$ & $64.5 \pm 0.3$ & $63.7-65.3$ & 1.02 \\
\hline P. oleaster & $58.7-65.0$ & $62.5 \pm 0.4$ & $61.6-63.4$ & $50.0-65.0$ & $62.3 \pm 0.8$ & $61.6-63.4$ & 1.00 \\
\hline P. schultziana & $52.5-75.0$ & $67.5 \pm 1.1$ & $65.2-69.8$ & $50.0-70.0$ & $63.3 \pm 1.0$ & $61.1-65.6$ & 1.06 \\
\hline
\end{tabular}

Table II. Measurements (in $\mu \mathrm{m}$ ) of pollen grains in polar view: equatorial diameter (EDPV); apocolpus side (AS) and polar area index (PAI) of pollen grains of Piptolepis species $(n=10)$. $x$ - arithmetic mean.

\begin{tabular}{|c|c|c|c|c|c|c|}
\hline \multirow[t]{2}{*}{ Species } & \multicolumn{2}{|c|}{ EDPV } & \multicolumn{2}{|c|}{ AS } & \multicolumn{2}{|c|}{ Polar area } \\
\hline & Range & $x^{-}$ & Range & $x^{-}$ & PAI & \\
\hline P. buxoides & $65.0-68.7$ & 66.7 & $25.0-30.0$ & 27.0 & 0.40 & small \\
\hline P. campestri & $60.0-62.5$ & 61.1 & $25.0-27.5$ & 26.0 & 0.42 & small \\
\hline P. ericoides & $72.5-75.0$ & 74.1 & $25.5-27.0$ & 26.5 & 0.35 & small \\
\hline P. gardneri & $57.5-62.5$ & 59.6 & $27.5-25.0$ & 27.0 & 0.45 & small \\
\hline P. glaziouana & $58.7-65.0$ & 62.1 & $20.0-30.0$ & 24.2 & 0.39 & small \\
\hline P. imbricata & $52.5-65.0$ & 61.6 & $25.0-26.5$ & 26.7 & 0.43 & small \\
\hline P. leptospermoides & $55.0-57.5$ & 57.0 & $25.0-27.5$ & 26.5 & 0.46 & small \\
\hline P. monticola & $65.0-70.0$ & 66.6 & $25.0-27.5$ & 26.0 & 0.39 & small \\
\hline P. oleaster & $61.2-66.2$ & 63.7 & $25.0-27.5$ & 25.6 & 0.40 & small \\
\hline P. schultziana & $66.2-75.0$ & 71.8 & $25.0-32.5$ & 29.5 & 0.41 & small \\
\hline
\end{tabular}

\section{DISCUSSION}

This is the first palynological study of the genus Piptolepis. Ten of the 13 species were investigated and found to have similar palynological characteristics. Within subtribe Lychnophorinae, only the genera Paralychnophora MacLeish (Souza-Souza et al. 2016) and Eremanthus Less. (Loeuille et al. 2012b) and one species of the genus Lychnophora Mart. (Marques et al. 2018) have been the focus of palynological studies.

It was possible to distinguish Piptolepis species on the basis of their pollen shape, sexine ornamentation, endoaperture shape, and presence or absence of endoapertures with median constriction. These characteristics were used to develop an identification key.

Homogeneity in exine ornamentation was observed (subechinolophate in most taxa, sublophate only in P. imbricata). Only $P$. campestris showed a Y-shaped structure in the apocolpium. Other important characters to distinguish between species were spine size and shape (disorganized and prostrate in $P$. monticola, elongated and narrow in P. oleaster, and conical in the other species).

Schultz-Bipontinus (1863) grouped species with narrow leaves and solitary capitula into 
Table III. Measurements (in $\mu \mathrm{m}$ ) of the apertures and layers of exine and spines of pollen grains of Piptolepis species $(n=10)$. sexine* - tetum + columella. DBS - distance between the spines.

\begin{tabular}{|c|c|c|c|c|c|c|c|c|c|c|}
\hline Species & \multicolumn{2}{|c|}{ Ectoaperture } & Endoaperture & \multicolumn{3}{|c|}{ Exine } & \multicolumn{3}{c|}{ Spine } \\
\hline & length & width & length & width & $\begin{array}{c}\text { total } \\
\text { exine }\end{array}$ & nexine & $\begin{array}{c}\text { sexine } \\
\text { * }\end{array}$ & length & width & DBS \\
\hline P. buxoides & 21.0 & 4.7 & 4.2 & 4.0 & 18.5 & 2.1 & 1.6 & 14.8 & 5.4 & 13.6 \\
\hline P. campestri & 25.2 & 6.0 & 4.2 & 9.8 & 14.6 & 2.5 & 2.5 & 9.6 & 6.0 & 8.8 \\
\hline P. ericoides & 25.8 & 4.1 & 8.8 & 10.0 & 15.5 & 1.6 & 1.9 & 12.0 & 4.0 & 11.7 \\
\hline P. gardneri & 30.6 & 3.0 & 2.0 & 2.6 & 13.6 & 1.4 & 2.5 & 9.7 & 4.2 & 9.5 \\
\hline P. glaziouana & 25.2 & 5.7 & 9.6 & 7.0 & 16.4 & 2.3 & 2.1 & 12.0 & 4.8 & 10.5 \\
\hline P. imbricata & 20.7 & 4.9 & 6.2 & 8.8 & 14.7 & 2.0 & 1.6 & 11.1 & 4.9 & 11.1 \\
\hline P. leptospermoides & 24.6 & 5.6 & 5.8 & 6.0 & 14.4 & 1.6 & 1.6 & 11.2 & 4.0 & 10.2 \\
\hline P. monticola & 25.0 & 4.2 & 7.6 & 10.0 & 15.9 & 1.5 & 1.6 & 12.8 & 7.0 & 12.1 \\
\hline P. oleaster & 25.4 & 6.0 & 5.0 & 8.0 & 14.2 & 1.7 & 2.5 & 10.0 & 4.2 & 8.2 \\
\hline P. schultziana & 28.5 & 9.4 & 10.8 & 10.0 & 14.5 & 1.4 & 1.5 & 11.6 & 4.7 & 10.9 \\
\hline
\end{tabular}

sect. Microphyllum, but, palynologically, these species differ in shape (prolate-spheroidal in $P$. leptospermoides and P. imbricata and oblatespheroidal in P. ericoides and P. buxoides) and ornamentation of the sexine, (sublophate only in P. imbricata).

Sect. Macrophyllum comprises species with broad leaves and grouped capitula. All species of this section have pollen grains with lalongate endoapertures. P. imbricata and P. ericoides, however, which are part of sect. Microphyllum, also have lalongate endoapertures. In this section, only P. monticola shows pollen grains with disorganized and prostrate spines and endoapertures with median contraction. P. oleaster pollen shows elongated and narrow spines, whereas $P$. campestris pollen has conical spines.

One of the three species described by Loeuille et al. (2012a), P. schultziana, could not be placed in the sections proposed by SchultzBipontinus (1863). The pollen grains of $P$. schultziana are similar to those of $P$. campestris, which belongs to sect. Macrophyllum. The species differ only in that P. schultziana pollen grains have sexine with disorganized muri that do not form a Y-shaped structure in the apocolpium. The pollen characters described here do not corroborate the infrageneric classification of Schultz-Bipontinus (1863), as pollen attributes were not unique to the proposed sections.

Piptolepis and Eremanthus have many palynological similarities regarding ornamentation. Loeuille et al.(2012b) investigated the palynotaxonomy of 20 of the 23 Eremanthus species and characterized pollen grains as oblate-spheroidal in most taxa, rarely prolatespheroidal or suboblate, amb subtriangular, tricolporate, and subechinolophate. The authors emphasized that variations in quantitative characteristics are not related to the macromorphological subdivision of the genus or to generic or specific limits. In the present study, it was observed that Piptolepis pollen grains are spheroidal in P. leptospermoides and P. oleaster, oblate-spheroidal in P. buxoides, P. ericoides, 
and P. glaziouana, and prolate-spheroidal in the other species. Subprolate pollen grains were not observed.

All Piptolepis species have pollen with amb subcircular, and most show sexine subechinolophate, as also observed in pollen grains of Eremanthus. P. imbricata pollen has the sexine sublophate, a pattern intermediate between echinate and subechinolophate. In agreement with the results of Loeuille et al. (2012b), it was found that the pollen characters of Piptolepis do not corroborate the division of the genus into sections. However, micro- and macromorphological pollen characters can be used for species discrimination. Loeuille et al. (2012b) reported only lalongate endoapertures, whereas, in the present study, we observed circular, slightly lalongate, lalongate, slightly lolongate, and lolongate endoapertures.

Paralychnophora pollen grains, according to Souza-Souza et al. (2016), are medium to large, oblate-spheroidal, amb subcircular in most species, polar area small and very small in a single taxon, and sexine subechinolophate. These characteristics are very similar to those observed in Piptolepis, especially regarding sexine ornamentation and its variations. The authors observed endoapertures with median constriction in six Paralychnophora species, whereas we observed median constriction only in three species. Souza-Souza et al. (2016) emphasized the importance of pollen grains to describe the taxonomy of Paralychnophora and developed an identification key based on pollen morphology. We underscore the importance of pollen grains in the taxonomy of Lychnophorinae, as palynological analyses revealed a set of consistent information for the diagnosis of Piptolepis.

Recently, Marques et al. (2018) described a new species of Lychnophora (L. semirii D. Marques \& J.N. Nakaj.) and characterized its pollen grain as prolate-spheroidal, subechinolophate, microperforate, and endoaperture lalongate, resembling the closely related genus Eremanthus. Similar characteristics are also seen in Piptolepis pollen, thereby demonstrating homogeneity among the pollen types of the subtribe Lychnophorinae. Piptolepis pollen can be characterized as "uncommon type A," which frequently occurs in Eremanthus (Loeuille et al. 2012b), Paralychnophora (Souza-Souza et al. 2016), and Lychnophora (Marques et al. 2018).

This study demonstrated the palynotaxonomic potential of Piptolepis pollen grains. Piptolepis pollen are quite similar to each other, but it is possible to distinguish taxa using qualitative and quantitative data. The results expand the knowledge of Piptolepis, providing elements that can assist in species placement and guide future studies aimed at the evolution of Lychnophorinae.

\section{Acknowledgments}

C.B.F. Mendonça and V. Gonçalves-Esteves extend their thanks to Conselho Nacional de Desenvolvimento Científico e Tecnológico (CNPq) for a research grant and Chamada Universal 2018 (Proc. 422903/2018-3) for V. Gonçalves-Esteves. All of the authors are grateful for funding from Auxílio Emergencial ao Museu Nacional, Fundação de Amparo à Pesquisa do Estado do Rio de Janeiro (FAPERJ) (Proc. 200.090/2019).

\section{REFERENCES}

BRINGEL JR JB, CÂNDIDO JB \& LOEUILLE B. 2019. A new species of Piptolepis (Lychnophorinae, Vernonieae, Asteraceae) from the Brazilian Central Plateau. Phytotaxa 399: 271.

CNCFLORA. 2020. Piptolepis imbricata in Lista Vermelha da flora brasileira versão 2012.2 Centro Nacional de Conservação da Flora. Disponível em <http://cncflora. jbrj.gov.br/portal/pt-br/profile/Piptolepis imbricata>. Acesso em 22 novembro 2020.

ERDTMAN G. 1960. Pollen morphology and plant taxonomy Angiosperms. Stockholm: Almqvist and Wiksell, 539 p.

FAEGRI G \& IVERSEN J. 1966. Textbook of modern pollen analysis, 2nd ed, Copenhagen: Scandinavian University Books, 295 p. 
HIND DJN. 2003. Flora of Grão-Mogol, Minas Gerais: Compositae (Asteraceae). Bol Bot São Paulo 21: 179-234.

JEFFREY CDJ \& HIND DJN. 1994. The typification of Piptolepis Sch.Bip. (Compositae), nom cons. International Association for Plant Taxonomy (IAPT). Taxon 43: 94-96.

KEELEY SC \& ROBINSON H. 2009. Vernonieae. In: Funk VA et al. (Eds). Systematics, evolution and biogeography of Compositae, Wien: International Association for Plant Taxonomy (IAPT), p. 439-469.

LOEUILLE B, KEELEY SC \& PIRANI JR. 2015b. Systematics and Evolution of Syncephaly in American Vernonieae (Asteraceae) with emphasis on the brazilian subtribe Lychnophorinae. Syst Bot 40: 286-298.

LOEUILLE B, SEMIR J, HIND DJN \& PIRANI JR. 2012a. Three new species of Piptolepis (Compositae: Vernonieae) from Minas Gerais, Brazil. Kew Bull 67: 11-18.

LOEUILLE B, SEMIR J, LOHMANN LG \& PIRANI JR. 2015a. A phylogenetic analysis of Lychnophorinae (Asteraceae: Vernonieae) based on molecular and morphological data. Syst Bot 40: 299-315.

LOEUILLE B, SEMIR J \& PIRANI JR. 2019. A synopsis of Lychnophorinae (Asteraceae: Vernonieae). Phytotaxa 398: 1-139.

LOEUILLE B, SOUSA-SOUZA RMB, ABREU VHR, MENDONÇA CBF \& GONÇALVES-ESTEVES V. 2012b. Pollen morphology of the genus Eremanthus Less. (Vernonieae-Asteraceae). Acta Bot Bras 26: 46-57.

MARQUES D, VIA-DEL-PICO GM \& NAKAJIMA JN. 2018. A new species of Lychnophora Mart. (Vernonieae: Asteraceae) from Minas Gerais State, Brazil. Syst Bot 43: 1051-1058.

MELHEM TS, CRUZ-BARROS MAV, CORREAA AMS, MAKINOWATANABE H, SILVESTRE-CAPELATO MSF \& GONÇALVES-ESTEVES V. 2003. Morfologia polínica em plantas de Campos do Jordão (São Paulo, Brasil). Bol Inst Bot 16: 16-104.

MENDONÇA CBF, CARRIJO TT, ESTEVES RL \& GONÇALVES-ESTEVES V. 2010. Lessingianthus (Vernonieae_Asteraceae): generic and infrageneric relationships based on pollen morphology. Nord J Bot 28: 376-384.

MENDONÇA CBF, ESTEVES RL \& GONÇALVES-ESTEVES V. 2007a. Palinotaxonomia de espécies de Lepidaploa (Cass.) Cass. (Vernoniinae - Compositae) ocorrentes no Sudeste do Brasil. Rev Bras Bot 30: 69-86.

MENDONÇA CBF, GONÇALVES-ESTEVES V, ESTEVES RL \& NUNES AD. 2009. Palynotaxonomy of Vernonanthura H. Rob. (Vernonieae, Asteraceae) species from Southeast Brazil. Rev Bras Bot 32: 647-662.
MENDONÇA CBF, SOUZA MA, GONÇALVES-ESTEVES V \& ESTEVES RL. 2007b. Palinotaxonomia de espécies de Chrysolaena H. Rob., Echinocoryne H. Rob. e Stenocephalum Sch.Bip. (Vernonieae-Compositae) ocorrentes no sudeste do Brasil. Acta Bot Bras 21: 627-639.

PEÇANHA AF, MENDONÇA CBF, GONÇALVES-ESTEVES V \& ESTEVES RL. 2001. Palinotaxonomia de espécies de Piptocarpha R. Br. (Compositae, Vernonieae). Bol Mus Nac Nova Ser Bot 112: 1-14.

PUNT W, HOEN PP, BLACKMORE S, NILSSON S \& LE THOMAS A. 2007. Glossary of pollen na spore terminology. Rev Palaeobot Palyno 143: 1-81.

ROBINSON H. 1999. Generic and subtribal classification of American Vernonieae. Smithson Contrib Bot 89: 1-116.

ROBINSON H. 2006. Vernonieae. In: Kadereit J \& Jeffrey C (Eds). The Families and Genera of Vascular Plants (K. Kubitzki, series ed.): Asterales. New York, Springer 8: 149-174.

ROBINSON H. 2007. Tribe Vernonieae. In: Kadereit J \& Jeffrey C (Eds). The Families and Genera of Vascular Plants Asterales. Berlin, Springer 8: 165-192.

SALGADO-LABOURIAU ML. 1973. Contribuição à Palinologia do Cerrado. Rio de Janeiro: Acad Bras Cienc, 273 p.

SALGADO-LABOURIAU ML, VANZOLINI PE \& MELHEM TS. 1965. Variation of polar axes and equatorial diameters in pollen grains of two species of Cassia. Grana Palyno 6: 166-176.

SCHULTZ-BIPONTINUS CH. 1863. Lychnophora Martius und einige benachbarte Gattungen. Jahresber. Pollichia 20/21: 321-439.

SINISCALCHI CM, SOUZA-SOUZA RMB, LOEUILLE B, PIRANI JR \& GONÇALVES-ESTEVES V. 2017. The systematic value of pollen morphology in Chresta Vell Ex DC. (VernonieaeAsteraceae). Rev Palaeobot Palyno 244: 182-191.

SOUZA-SOUZA RMB, LOEUILLE B, MENDONÇA CBF, ESTEVES RL \& GONÇALVES-ESTEVES V. 2016. Pollen morphology of the genus Paralychnophora (Vernonieae-Asteraceae). Palynology 40: 1-9.

\section{APPENDIX 1}

Material examined:

P. buxoides (Less.) Sch.Bip. - Brasil, Minas Gerais, Santana do Riacho Km 127, Parque Nacional da Serra do Cipó, Martinelli, G. 2638, 
16/VII/1977 (RB). Brasil, Minas Gerais, Serra do Cipó, Km 137, Estrada de Conceição, Santa Lucia, *Mello Barreto 8543, 25/XI/1938 (HB).

P. campestris Semir and Loeuille - Brasil, Minas Gerais, Estrada para Biribiri, Diamantina, Nakajima, J.N. and Romero, R. 3090, 30/II/2001 (HUFU).

P. ericoides Sch.Bip. - Brasil, Minas Gerais, Serra do Cipó. k.135, Mello Barreto, 04/l/1938 (R32919). Brasil, Minas Gerais, Serra do Cipó, Heringer and Castellano 5927, 03/03/1958 (R). Brasil, Minas Gerais, Serra do Caraça, E. Pereira 2586, 22/III/1957 (HB).

P. gardneri Baker - Brasil, Minas Gerais, Serro. Estrada Serro-Milho Verde, a 9 km de Milho Verde, próximo a três Barras, M.M. Saavedra, et al. 877, 25/V/2009 (R).

P. glaziouana Beauverd - Brasil, Minas Gerais, Diamantina Km 350 on MG-259, WR Anderson 35435, 05/II/1972 (HB). Diamantina, Guinda, G. Hatschbach, 27399, 07/IX/197 (RB)

P. imbricata (Gardner) Sch.Bip. - Brasil, Minas Gerais, Parque estadual do Biribiri, Lapa do forno. Estrada Diamantina-Mendanha, ca. 10 km do Campus da Universidade, Romero, R. et al., 19/V/2011 (HUFU).

P. leptostemoides (Mart. ex DC.) Sch.Bip. Brasil, Estado, Minas Gerais, Diamantina. Estrada para Mendanha, a $10 \mathrm{~km}$ de Diamantina, $\mathbf{M}$. Merguro et al., 12/X/1984 (R234268).

P. monticola Loeuille - Brasil, Minas Gerais, Pico do Itambé, Pico do Itambé, Santo Antônio do Itambé, Souza, V.C. et al. 21079, 07/IV/1998 (HUFU).

P. oleaster (Mart. ex DC.) Sch.Bip. - Brasil, Minas Gerais, Serro. Alto do Pico do Itambé, Magalhães, MG 1575, 05/V/1942 (HB).

P. schultziana Loeuille \& D.J.N. Hind - Brasil, Minas Gerais, Santana de Pirapama Serra do Cipó, acesso pela Faz. Inhame. Trilha da Senhorinha, primeiro platô, Zappi, DC 1955, 09/III/2009 (RB).

\section{How to cite}

SOUZA-SOUZA RMB, DE SOUSA GKR, ESTEVES RL, MENDONÇA CBF \& GONÇALVES-ESTEVES V. 2022. Importance of palynology in the taxonomy of Piptolepis Sch.Bip. (Asteraceae: Lychnophorinae), a genus endemic to Brazil. An Acad Bras Cienc 94: e20201244. DOI 10.1590/00013765202220201244.

Manuscript received on August 7, 2020;

accepted for publication on February 14, 2021

RAQUEL M.B. SOUZA-SOUZA'

https://orcid.org/0000-0001-6658-7957

GRACE K.R. DE SOUSA

https://orcid.org/0000-0001-8509-2204

\section{ROBERTO L. ESTEVES ${ }^{2}$}

https://orcid.org/0000-0002-2884-9538

\section{CLAUDIA B.F. MENDONÇA'}

https://orcid.org/0000-0003-4219-6147

\section{VANIA GONÇALVES-ESTEVES \\ https://orcid.org/0000-0002-2803-6027 \\ 'Universidade Federal do Rio de Janeiro, Museu Nacional, Departamento de Botânica, Laboratório de Palinologia, Quinta da Boa Vista, s/n, São Cristóvão, 20940-040 Rio de Janeiro, RJ, Brazil \\ ${ }^{2}$ Universidade do Estado do Rio de Janeiro, Departamento de Biologia Vegetal, Av. São Francisco Xavier, 524, Maracanã, 20550-900 Rio de Janeiro, RJ, Brazil}

Correspondence to: Vania Gonçalves-Esteves

E-mail:esteves.vr@gmail.com

\section{Author contributions}

R.M.B. Souza-Souza and R.L. Esteves contributed to the genus taxonomy, G.K.R. de Sousa, with the treatment and measurements of pollen grains, C.B.F. Mendonça and V. Gonçalves-Esteves confirmed the descriptions and discussion of the results, prepared the pollen key and organized the manuscript for publication.

\section{(cc) BY}

